\title{
The Contribution and Reduction of Narrative Theology to Biblical Hermeneutics in the Postmodern Era
}

\author{
Oscard L. Tobing ${ }^{\circledR}$ \\ Institut Agama Kristen Negeri Kupang, Indonesia \\ oscard.tobing@gmail.com
}

\begin{abstract}
This research examines narrative theology, which began to develop in the 1970s in the United States, and is now widely practiced in theological discourses, including in Indonesia. This theology, sometimes called postliberal theology, uses the postmodern interpretation paradigm, which seeks the meaning "in front of" the text (readers-oriented). The intended readers are the community, who have the same language, culture, and traditions. It turns out that narrative theology, which initially served as a theological reflection on Christianity's claims to the biblical texts, has shifted into a hermeneutical lens in reading the biblical texts. Using analytical studies of library research and systematic review, the author discusses the contours of narrative theology starting from the thoughts of its pioneers (such as Hans W. Frei, George A. Lindbeck, Stanley Hauerwas, and Sally McFague), describing its characteristics, and evaluating them. The analysis results are presented in two points. The first is an appreciation of the contributions of narrative theology, i.e., simple-practical, confessional-dogmatic, relational, and inductive. The second is an evaluation of some reductive aspects of narrative theology, i.e., postmodern hermeneutics; a disregard of historicity and genre diversity; traditional-dogmatic fideism; sectarianism; and pragmatism.
\end{abstract}

\section{Research Highlights}

- The author traces the contours of narrative theology using library research and systematic review approach, beginning with the thoughts of its pioneers, explaining, analyzing, and assessing its characteristics.

- The purpose of this research is to investigate the contributions of narrative theology and analyze its certain reductive features for biblical hermeneutics and theology in the postmodern era.

Article history

Submitted 14 March 2021

Revised 6 May 2021

Accepted 4 June 2021

\section{Keywords}

hermeneutics; narrative

theology; postliberal; postmodern; tradition; community

(C) 2021 by author.

Licensee Veritas: Jurnal

Teologi dan Pelayanan.

This article is licensed under the term of the Creative

Commons Attribution-

NonCommercial-ShareAlike 4.0 International

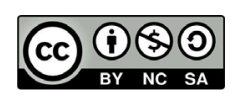




\title{
Kontribusi dan Reduksi Teologi Naratif bagi Hermeneutika Biblikal di Era Pascamodern
}

\author{
Oscard L. Tobing (iD \\ Institut Agama Kristen Negeri Kupang, Indonesia \\ oscard.tobing@gmail.com
}

\begin{abstract}
Abstrak: Artikel ini bertujuan untuk mengkaji teologi naratif yang mulai berkembang sejak tahun 1970-an di Amerika Serikat, dan kini banyak dipraktikan dalam berteologi, termasuk di Indonesia. Teologi yang kadang disebut teologi pascaliberal ini memakai paradigma tafsir pascamodern, yang mencari makna "di depan teks" (berorientasi pada pembaca dan dunianya). Pembaca yang dimaksud adalah komunitas yang mempunyai bahasa, budaya, dan tradisi yang sama. Ternyata teologi naratif yang awalnya berfungsi sebagai refleksi teologis terhadap klaim kekristenan telah bergeser menjadi lensa hermeneutis dalam membaca teks Alkitab. Dengan menggunakan analisis studi kepustakaan dan tinjauan sistematis, penulis membahas kontur teologi naratif mulai dari pemikiran para pelopornya (seperti Hans W. Frei, George A. Lindbeck, Stanley Hauerwas, dan Sally McFague), menjelaskan karakteristiknya, serta mengevaluasinya. Hasil analisis disajikan dalam format apresiasi terhadap kontribusi teologi naratif (sederhanapraktis, konfesional-dogmatis, relasional, dan induktif) dan evaluasi terhadap reduksi (hermeneutika pascamodern, pengabaian historisitas dan keragaman genre, fideisme tradisionaldogmatis, sektarian, serta pragmatisme). Hasil analisis disajikan dalam dua poin. Pertama, apresiasi terhadap kontribusi teologi naratif, yaitu sederhana-praktis, konfesional-dogmatis, relasional, dan induktif. Kedua, evaluasi terhadap beberapa aspek reduktif dari teologi naratif, yaitu hermeneutika pascamodern; mengabaikan historisitas dan keragaman genre; fideisme dogmatis tradisional; sektarianisme; dan pragmatisme.
\end{abstract}

Kata-kata kunci: hermeneutika; teologi naratif; pascaliberal; pascamodern; tradisi; komunitas

\section{PENDAHULUAN}

Titik awal kemunculan teologi naratif selalu dikaitkan dengan nama Hans W. Frei dan George A. Lindbeck, yang merupakan sepasang kolega di Yale University. Di antara mereka, Frei yang secara intens mengenalkan gagasan tentang "naratif" dalam karya The Eclipse of Biblical Narrative (1974) dan The Identity of Jesus Christ (1975). Dalam perkembangan teologi Kristen, Frei dan Lindbeck

${ }^{1}$ Jacob L. Goodson, Narrative Theology and the Hermeneutical Virtues: Humility, Patience, Prudence (Lanham: Lexington, 2015), 1; John Allan Knight, Liberalism versus juga dikenal sebagai pelopor teologi pascaliberal. Oleh karena itu, tidaklah mengherankan bahwa selalu dijumpai posisi teologi yang berkelindan antara teologi naratif dan teologi pascaliberal. ${ }^{1}$

Teologi naratif merupakan respons terhadap studi kritis Alkitab modern yang terlalu historis, yang merekonstruksi sumber, mencari sejarah editorial teks supaya berfokus pada latar belakang, penerima, penulis, dan penyunting

Postliberalism: The Great Divide in Twentieth-Century Theology (Oxford: Oxford University Press, 2013), 155. 
aslinya. ${ }^{2}$ Sangat deskriptif. Kedua, sebagai teologi yang juga dominan waktu itu, teologi sistematika tradisional pun dianggap gagal dalam menafsir individu, dunia, dan Tuhan. Dalam hal ini, John Klaasen menyarankan agar pendekatan naratif bisa membuat makna (meaning making) melalui penalaran yang tertanam dalam pengalaman. ${ }^{3}$ Faktor lainnya adalah bahwa pada tiga dekade terakhir sering muncul pertanyaan tentang identitas orang Kristen di tengah gereja dan masyarakat. Beberapa teolog bergumul dengan pertanyaan tentang makna identitas Kristen di dunia pascakristen dan pascamodern. Banyak kelompok ras atau etnis, kaum perempuan (feminisme), dan orang Kristen di komunitas nonbarat menolak interpretasi orang Kristen kulit putih dan pria (maskulin), serta mulai mengeksplorasi paradigma baru untuk mempraktikkan teologi. ${ }^{4}$ Secara historis, ketiga faktor di atas adalah permasalahan yang menjadi konteks lahirnya teologi naratif, yaitu Amerika Utara. Namun, kini semua itu telah menjadi pergumulan bagi banyak orang Kristen di lokasi-lokasi lainnya. Tujuan hermeneutis dari teologi naratif bukan lagi menjawab pertanyaan, "apa arti asli ayat" atau "apa arti ayat untuk masa kini," tetapi berupaya untuk menjawab pertanyaan, "Bagaimana orang Kristen (di setiap lokasi) memaknai teks?"

Dalam perkembangannya, sikap dan respons terhadap teologi naratif tidak selalu berada pada format dan posisi yang sama. Di satu sisi, melihat pemanfaatan teologi ini dalam bidang

\footnotetext{
${ }^{2}$ David F. Ford, "Narrative Theology," diedit oleh R.J. Coggins dan J.L. Houlden, The SCM Dictionary of Biblical Interpretation (London: SCM, 2003), 489.

${ }^{3}$ John Klaasen, "Practical Theology and Narrative: Contours and Markers," Stellenbosch Theological Journal 3, no. 2 (December 2017): 459, https://doi.org/10.17570/ stj.2017.v3n2.a21.

${ }^{4}$ George W. Stroup, "Narrative Theology," dalam The Cambridge Dictionary of Christian Theology, diedit oleh Ian A. McFarland et al. (Cambridge: Cambridge University Press, 2011), 331.

${ }^{5}$ R. Ruard Ganzevoort, "Narrative Approaches," dalam The Wiley-Blackwell Companion to Practical Theology, diedit oleh Bonnie J. Miller-McLemore (Chichester: Wiley-Blackwell, 2012), 217-218.
}

teologi, etika, sastra, psikologi, layanan pastoral, dan pendidikan agama, maka teologi naratif sangat dibutuhkan. ${ }^{5}$ Tetapi di sisi yang lain, kritik Bruce D. Marshall, Alister E. McGrath, dan Kevin J. Vanhoozer memperlihatkan sisi reduktif teologi naratif terhadap teologi Kristen. ${ }^{6}$ Terkait dengan hal itu, artikel ini hendak menampilkan dimensi kontributif dan reduktif dari teologi naratif, yang pada akhirnya bisa menjadi pemikiran dan pertimbangan orang Kristen dalam berteologi.

\section{METODE PENELITIAN}

Adapun kerangka kerja analisis yang diterapkan adalah memanfaatkan metode kepustakaan dan systematic review, sebagai bagian dari jenis penelitian kualitatif. Hasil penelitian disajikan dalam format: redefinisi, praanggapan (para pionir dan pemikirannya), tipe, dan karakteristik teologi naratif. Klimaks dari analisis berada pada subjudul apresiasi dan evaluasi, yang merupakan hasil identifikasi apakah teologi naratif bersifat kontributif atau reduktif bagi teologi Kristen.

\section{HASIL DAN PEMBAHASAN}

\section{Redefinisi Naratif}

Di dalam perkembangannya, terdapat beberapa definisi teologi naratif yang bisa ditemui, dan hal itu dijabarkan dalam hasil survei berikut. ${ }^{7}$ Stroup menyatakan bahwa teologi

\footnotetext{
${ }^{6}$ Bruce D. Marshall, "Introduction: The Nature of Doctrine after 25 Years," dalam The Nature of Doctrine: Religion and Theology in A Postliberal Age, oleh George A. Lindbeck, 25 th Anniversary Edition (Louisville: Westminster John Knox, 2009), vii-xxvii; Alister E. McGrath, $A$ Passion for Truth: The Intellectual Coherence of Evangelicalism (Downers Grove: InterVarsity, 1996); Kevin J. Vanhoozer, The Drama of Doctrine: A Canonical-Linguistic Approach to Christian Theology (Louisville: Westminster John Knox, 2005).

${ }^{7}$ Dalam Kamus Besar Bahasa Indonesia (KBBI), istilah "naratif" mempunyai dua bentuk kelas kata, yaitu adjektiva dan nomina. Secara adjektif, kata "naratif" berarti "bersifat narasi" atau "bersifat menguraikan (menjelaskan)" sedangkan dalam kelas kata nomina istilah "naratif"
} 
naratif bukanlah sebuah gerakan atau mazhab teologi, melainkan salah satu tema dalam teologi Kristen, yang sejenis dengan tema-tema teologis lainnya. ${ }^{8}$ Sementara itu, Harvey mengartikan teologi ini sebagai representasi dari berbagai varietas perhatian, penilaian, serta proyek metodologis dan teologis yang berusaha untuk memulihkan relevansi kisah naratif dari Alkitab serta kisah naratif gereja, baik secara individual maupun komunal. ${ }^{9} \mathrm{Di}$ tempat yang berbeda, Comstock mempunyai pandangan berbeda dengan Stroup dan Harvey, di mana teologi naratif dipahami sebagai refleksi atas klaim religius yang tertanam dalam sebuah cerita. ${ }^{10}$ Tampaknya Jones menjelaskan posisi yang agak sama dengan Comstock, di mana tekanan berada pada pentingnya narasi bagi refleksi teologis. ${ }^{11}$ Usulan lain datang dari Fackre yang beragumen bahwa teologi naratif merupakan suatu diskursus tentang Allah dalam bentuk latar cerita. ${ }^{12}$ Narasi diyakini menjadi gambaran konklusif untuk menerjemahkan iman dan memahaminya. Penggambaran realitas dalam hal plot, koherensi, gerakan, dan klimaks adalah pusat dari semua bentuk percakapan tentang Tuhan.

Ada beberapa kata kunci yang bisa ditemui dari sejumlah definisi di atas, antara lain, "tema" (Stroup), "perhatian atau penilaian" (Harvey), "refleksi" (Comstock dan Jones), dan "diskursus" (Fackre). Tampaknya, secara eksplisit, seluruh diksi dari setiap definisi belum mengarah pada hermeneutika. Teologi

berarti "prosa yang subjeknya merupakan suatu rangkaian kejadian." Pada tulisan ini, kelas kata yang dipakai pada judul dan substansi penelitian adalah nomina, lih. $K B B I$ Daring, s.v. "naratif," diakses 6 Mei 2021, https://kbbi. kemdikbud.go.id/entri/naratif.

${ }^{8}$ Stroup, "Narrative Theology," 331.

${ }^{9} \mathrm{~T}$. Harvey, "Narrative Theology," dalam Global Dictionary of Theology: A Resource for the Worldwide Church, diedit oleh William A. Dyrness and Veli-Matti Kärkkäinen (Downers Grove: InterVarsity, 2009), 601.

${ }^{10}$ Gary L. Comstock, "Two Types of Narrative Theology," Journal of the American Academy of Religion LV, no. 4 (1987): 678, https://doi.org/10.1093/jaarel/LV.4.687.

${ }^{11}$ L. Gregory Jones, "Narrative Theology," dalam The Blackwell Encyclopedia of Modern Christian Thought, diedit oleh Alister E. McGrath (Oxford: Blackwell, 1993), 395. naratif masih diartikan sebuah teologi, bukan hermeneutika. Namun kini peran dan fungsinya lebih dari pada itu. Indikasi tersebut bisa terlihat dari pemikiran beberapa teolog belakangan, antara lain: David A. Hampton, Jacob L. Goodson, dan Timo Eskola. ${ }^{13}$ Bahkan survei yang dilakukan John Navone memperlihatkan kontribusi teologi naratif sebagai lensa teori untuk menjelaskan dan merumuskan teologi moral (etika), teologi fundamental, pengantar studi agama-agama, pendidikan agama Kristen, teologi biblika, dan spiritualitas. ${ }^{14}$ Selain itu, pemanfaatan teologi ini ternyata tidak hanya terjadi di kalangan Kristen. Survei-survei di atas menghadirkan kesan bahwa telah terjadi pergeseran arti dan fungsi teologi naratif. Mungkin memang itulah tujuan awal dari kemunculannya, bahwa teologi ini merupakan pendekatan pragmatis atas klaim Kristen dalam merelevansikan narasi Alkitab dengan narasi orang percaya di era pascamodern ini.

\section{Praanggapan: Para Pionir dan Pemikirannya}

$$
\text { Hans W. Frei (1922-1988) }
$$

Karya awal teologi naratif bisa dikaitkan dengan esai H. Richard Niebuhr yang berjudul "The Meaning of Revelation," dalam mengenalkan The Story of Our Lives (1941). Karenanya dia dijuluki Bapak Teologi Naratif Kontemporer. ${ }^{15}$ Tetapi masa itu, perkembangan

\footnotetext{
${ }^{12}$ Gabriel Fackre, "Narrative Theology: An Overview," Interpretation: A Journal of Bible and Theology 37, no. 4 (October 1983): 343, https://doi.org/10.1177/002096438303 700402.

${ }^{13}$ David Hampton, Narrative Theology as A Hermeneutic Approach (Morrisville.: Lulu, 2009); Goodson, Narrative Theology and the Hermeneutical Virtues; Timo Eskola, $A$ Narrative Theology of the New Testament: Exploring the Metanarrative of Exile and Restoration (Tübingen: Mohr Siebeck, 2015).

${ }^{14}$ John Navone, "Narrative Theology and Its Uses: A Survey," Irish Theological Quarterly 52, no. 3 (September, 1986): 212-227, https://doi.org/10.1177/002114008605200304.

${ }^{15}$ Wentzel van Huyssteen, "Narrative Theology: An Adequate Paradigm for Theological Reflection?," HTS
} 
studi naratif dalam dunia teologi tidak semasif tahun 1970-an dan sesudahnya, atau tepatnya dimulai sejak karya Frei, The Eclipse of Biblical Narrative (1974) dan sekuelnya, The Identity of Jesus Christ (1975). Frei lahir di Jerman, namun ia adalah seorang teolog berkebangsaan Amerika Serikat yang mengajar di Yale University. Kritik Frei merupakan reaksi terhadap hermeneutika biblika modern, (abad ke-18 dan ke-19 yang berkembang di Inggris dan Jerman) yang berporos pada kritik historis dan apologetika agama. Berdasarkan kedua poros ini, maka fakta sejarah sangat diperlukan untuk wahyu, dan kebermaknaan wahyu bergantung pada pengaturannya dalam konteks agama atau moral yang lebih luas. Bagi Frei sebuah hermeneutika sebaiknya berporos pada struktur naratif Alkitab, yang diyakini orang Kristen sebagai firman Allah. ${ }^{16}$

Pada bagian introduksi bukunya (The Eclipse of Biblical Narrative), Frei tetap menilai bahwa hermeneutika adalah kebutuhan yang penting bagi kekristenan. Tetapi ia mengubah arah hermeneutika menjadi kegiatan yang hendak memasukkan pemikiran, pengalaman, dan realitas ekstrabiblikal ke dalam satu dunia nyata yang dirinci dan dapat diakses oleh kisah Alkitab, bukan sebaliknya. ${ }^{17}$ Operasi kritik Frei adalah bersifat intratekstual, yang berbeda dengan operasi studi kritik sastra yang lebih bersifat intertekstual, menggambarkan relasi antar dunia teks. Pada analisis Frei, ada tiga fitur yang perlu diperhatikan dalam membaca Alkitab sebagai narasi realistis. Pertama, jika sebuah cerita Alkitab dibaca secara literal, maka hal itu pastilah merujuk dan menggambarkan kejadian-kejadian historis aktual. Kedua, jika dunia yang digambarkan oleh kisah-kisah Alkitab adalah satu

Teologiese Studies / Theological Studies 45, no. 4 (Januari 1989): 769, https://doi.org/10.4102/hts.v45i4.2327.

${ }^{16}$ Hans W. Frei, The Eclipse of Biblical Narrative: $A$ Study in Eighteenth and Nineteenth Century Hermeneutics (New Haven: Yale University Press, 1974), 124.

${ }^{17}$ Ibid., 3.

${ }^{18}$ Ibid., 2-3. dunia yang tunggal (yaitu, satu arus temporal tunggal), maka cerita itu sendiri harus menceritakan satu kisah kumulatif. Terakhir, kedua pembacaan cerita itu digabungkan menjadi satu cerita kumulatif tunggal dengan cara membuat cerita-cerita sebelumnya menjadi gambaran atau tipe dari cerita-cerita selanjutnya. $^{18}$

Dalam pandangan Frei, bacaan figuratif seperti di atas tidak bertentangan dengan pengertian literal, melainkan menjadi perpanjangan alami dari bacaan tersebut. Lantas karena kisah-kisah alkitabiah menceritakan satu kisah kumulatif dari satu-satunya dunia nyata, maka kisah-kisah ini juga harus menceritakan kisah zaman sekarang dan individuindividu di dalamnya. Perilaku ini harus mendeskripsikan dunia atau narasi Alkitab. ${ }^{19}$ Seorang Kristen harus memahami dan menjalani hidupnya sendiri sehingga masuk akal sebagai bagian dari kisah Alkitab kumulatif tunggal. Frei meyakini bahwa para penafsir Alkitab umumnya setuju bahwa fitur naratif yang kumulatif, realistis, atau mirip sejarah (history-like) adalah karakteristik dari Alkitab, meskipun mereka jelas harus menyangkal bahwa itu meliputi seluruh Alkitab atau bahwa itu adalah satu-satunya fitur literer bahkan dari beberapa cerita yang memang memperlihatkannya. ${ }^{20}$

Teologi modern telah melakukan wrong turn dalam berteologi, sebab belokan ini merupakan peralihan menuju pemahaman deskriptif atau referensial tentang makna teks-teks Alkitab. ${ }^{21}$ Frei menolak cara kerja pendekatan modern yang terlalu deskriptif tersebut. Menurutnya, tidak perlu menerapkan pola meaning-as-reference, melainkan arti tepat

\footnotetext{
${ }^{19}$ Andreas Himawan, "Tekstualitas dan Intratekstualitas dalam Hermeneutika Pascaliberalisme," Veritas : Jurnal Teologi dan Pelayanan 1, no. 2 (Maret, 2000): 152, https://doi.org/10.36421/veritas.v1i2.43.

${ }^{20}$ Frei, The Eclipse of Biblical Narrative, 15-16.

${ }^{21}$ Knight, Liberalism versus Postliberalism, 161-162.
} 
Alkitab diperoleh seperti yang tertulis. ${ }^{22}$ Teks yang naratif itu biarlah tetap naratif. Tidak perlu membuatnya "relevan" dan "aplikatif" bagi dunia modern. Sebab bagi Frei, narasi Alkitab adalah realitas riil yang dapat mengatasi dunia masa kini. Pembacaan seperti itu bertujuan untuk mendeskripsikan dunia simbolis sebagai kerangka interpretasi terhadap masa kini. Singkatnya, narasilah yang membentuk dunia modern dan komunitas Kristen. ${ }^{23}$

\section{George A. Lindbeck (1923-2018)}

Lindbeck adalah teolog Lutheran berkebangsaan Amerika Serikat, yang lahir di Cina. Dia menempuh studi akademik di Yale University untuk menggapai gelar sarjana dan pascasarjana. Sejalan dengan pemikiran koleganya, Frei, Lindbeck pun membuat respons terhadap teori tentang agama dan doktrin sebelumnya. Dia menolak premis modern mengenai subjek yang bisa mengetahui secara mandiri. Alasannya, pengalaman dan penalaran seorang individu pasti selalu dibentuk oleh tradisi dan bahasa yang digunakan, termasuk budayanya. ${ }^{24}$

Lindbeck mengategorikan teori yang telah ada ke dalam tiga tipe, yaitu proposisionalkognitif, pengalaman-ekspresif, serta gabungan tipe pertama dan tipe kedua, seperti yang ditunjukkan oleh beberapa teolog Katolik (seperti Karl Rahner dan Bernard Lonergan). ${ }^{25}$ Ketiga tipe tersebut dinilai Lindbeck tidak memberi ruang bagi kemungkinan rekonsiliasi doktrinal jika tidak ada yang mengalah. ${ }^{26}$ Agama selalu muncul dalam dalam budaya tertentu dan medianya adalah bahasa, sehingga teologi seharusnya dibangun di atas dasar budaya dan bahasa, di mana teologi itu berada. ${ }^{27}$ Bagi orang Kristen wujud

\footnotetext{
${ }^{22}$ Frei, The Eclipse of Biblical Narrative, 86-104; Vanhoozer, The Drama of Doctrine, 10-11.

${ }^{23}$ Himawan T. Pambudi, "Narasi Bima Bertemu Dewaruci: Metode Teologi Injili di Indonesia dalam Era Pascamodern," Jurnal Amanat Agung 7, no. 2 (2011): 289-311.

${ }^{24}$ Lindbeck, The Nature of Doctrine, 101.
}

konkret bahasa itu adalah teks Alkitab. Di sini Lindbeck menetapkan narasi Kristen (narasi Alkitab) sebagai "kacamata" yang harus dipakai oleh seorang teolog untuk melihat dunia. Pemahaman demikian mendorong Lindbeck menetapkan model "kultural-linguistik" sebagai medium yang membentuk agama dan pemikiran.

Ketika membicarakan "kebenaran," Lindbeck melihatnya melalui tiga cara, yaitu kategorial (proporsional), intrasistematis (koherensi), dan ontologis (korespondensi) ${ }^{28}$ Dengan memanfaatkan filsafat bahasa, kebenaran kategorial merujuk pada "cara" seseorang menjadi religius. Apa itu agama dan apa yang diajarkan agama, tidaklah penting. Kebenaran intrasistematis lebih penting daripada kebenaran ontologis. Sebuah pernyataan tidak bisa benar secara ontologis, kecuali benar secara intrasistematis. Tetapi kebenaran intrasistematis sangat mungkin tanpa kebenaran ontologis. Dalam teologi Lindbeck, ketiga kebenaran tersebut dirangkul.

\section{Sesudah Frei dan Lindbeck}

Di masa sesudah karya Frei dan Lindbeck, teologi naratif mengalami perkembangan dan perluasan makna dan aplikasinya. Salah satu teolog yang melakukannya adalah Stanley Hauerwas. Selain sebagai seorang teolog, Hauerwas juga dikenal sebagai ahli etika dari Amerika Serikat. Tulisannya yang terkait dengan penelitian ini adalah Why Narrative? Reading in Narrative Theology (1997). John Berkman dalam introduksi buku The Hauerwas Reader (2001) yang disuntingnya itu, menganggap Hauerwas sebagai teolog yang terdepan dalam mengembangkan

${ }^{25}$ Ibid., 2

${ }^{26}$ Ibid., 3.

${ }^{27} \mathrm{Di}$ sini tampak begitu kuat pengaruh antropolog Clifford Geertz dan filsuf bahasa Ludwig Wittgenstein, lih. Lindbeck, The Nature of Doctrine, xxxi. ${ }^{28}$ Ibid., 26-64. 
teologi naratif. ${ }^{29}$ Narasi dinilai sebagai pusat refleksi teologis dan etis Kristen, meskipun masih ada yang bingung dalam menerapkannya. ${ }^{30}$ Hauerwas menghubungkan kisah-kisah kehidupan kita yang berkaitan dengan karakter dan kebajikan dalam upaya untuk mengklaim kembali pentingnya narasi dalam etika dan teologi. Dengan bantuan teologi naratif, orang Kristen dapat melibatkan studi tentang Tuhan dan berbicara tentang Tuhan yang bermanfaat dalam pembentukan kehidupan orang Kristen sesuai pola kehidupan Yesus.

Selain Hauerwas, teolog naratif lainnya adalah Sallie McFague. Speaking in Parables (1975) adalah karya awal McFague yang bisa dikaitkan dengan teologi naratif. Tujuan teologi yang dikembangkan McFague adalah "to make it possible for the gospel to heard in our time." ${ }^{31}$ Demi tujuan itu, maka cara berteologi harus disesuai dengan konteks, yang disebut McFague in our time, yakni era pascamodern. Menurutnya, metode seperti itu pernah dipakai oleh Yesus, misalnya perumpamaan, puisi, dan kisah otobiografi. Dengan cara yang sama ketiganya dapat menjadi model refleksi teologis, sebab di dalamnya tercakup bahasa, kepercayaan dan kehidupan yang berarti dan relevan. ${ }^{32}$ Tetapi dalam hal ini, perumpamaan menjadi sumber utama berteologi, sehingga bahasa metaforis menjadi bahasa primer dan yang sekunder ialah bahasa konseptual. Dewasa ini teologi tidak bisa didengarkan hanya dengan mengambil bentuk pemikiran konseptual dan sistematis, melainkan dengan menceritakan kisah serta menyajikan gambaran-gambaran puitis. Yang diperlukan ialah jalan tengah di antaranya. ${ }^{33}$ Teologi metafora McFague merupakan teologi perantara yang memanfaatkan ciri

\footnotetext{
${ }^{29}$ Stanley Hauerwas, The Hauerwas Reader, diedit oleh John Berkman dan Michael G. Cartwright (Durham: Duke University Press, 2001), 7.

${ }^{30}$ Stanley Hauerwas, Why Narrative? Readings in Narrative Theology (Eugene: Wipf \& Stock, 1997), 1.

${ }^{31}$ Sallie McFague, Speaking in Parables: A Study in Metaphor and Theology (Philadelphia: Fortress, 1975), 1.

${ }^{32}$ Ibid., 1-2.
}

metaforis dari perumpamaan Yesus. Tentang hal ini dijelaskan lebih detail pada karya McFague yang lain, yaitu Metaphorical Theology: Models of God in Religious Language (1982). Bagi McFague, perumpamaan merupakan metafora yang diperluas dan tak tergantikan. Alkitab menjadi metafora firman atau cara Allah, dan Yesus adalah metafora Allah. ${ }^{34}$ Akhirnya, ini menjadi model teologis bagaimana orang Kristen hidup di dunia. Seperti apa model yang dimaksud, harus terlebih dahulu mengenal akar metafora (yang baru) itu sendiri, yaitu "kerajaan Allah." Tema ini ditunjukkan dalam perumpamaanperumpamaan Yesus dan di dalam Yesus sebagai perumpamaan Allah yang menggambarkan mode keberadaan dalam dunia sebagai anugerah bebas dari Allah. Ini berarti bahwa Yesus berperan ganda, sebagai "proklamator" kerajaan dan di saat yang sama menjadi "jalan" menuju kerajaan itu. ${ }^{35}$ Fokus teologi bukan tentang natur Allah atau manusia, tetapi pada kualitas "relasi", sebagai cara seluruh makhluk berada di bawah pemerintahan Allah. ${ }^{36}$ Akar metafora dan kualitas itu perlu dibuktikan melalui bahasa variatif yang dipakai untuk menganalisis dan menginterpretasinya, dalam bentuk refleksi teologis. Di dalam teologi Kristen, menurut McFague, refleksi teologis bertempat di pengakuan, liturgi, dan etika, dan ketiganya berbentuk naratif. ${ }^{37}$

\section{Tipe Teologi Naratif}

Ketegangan eksplisit mengenai tipe teologi naratif sebenarnya sudah tersirat dalam karya Niebuhr, yang membuat perbedaan penting dan jauh antara sejarah "internal" dan "eksternal." Sejarah internal berkaitan dengan

\footnotetext{
${ }^{33}$ Sallie McFague, Metaphorical Theology: Models of God in Religious Language (Philadelphia: Fortress, 1982), 23.

${ }^{34}$ Ibid., 50-55.

${ }^{35}$ Ibid., 108-109.

${ }^{36}$ Ibid., 114.

${ }^{37}$ Ibid., 106.
} 
deskripsi diri komunitas Kristen dalam kaitannya dengan pengalaman mereka saat ini tentang penyataan ilahi. Sedangkan sejarah eksternal, di sisi lain, adalah sejarah masa lalu yang dipahami dari perspektif pengamat, dan itu bersifat objektif sehingga bisa mengajukan pertanyaan penyelidikan ilmiah. ${ }^{38}$ Terkait hal itu, Comstock memberi analisis yang mencerahkan tentang perbedaan ini. Dia membedakan teologi naratif menjadi dua tipe. Pertama, teologi naratif pure yang berkembang di Yale University. Teologi tipe ini yakin bahwa bentuk-bentuk sastra itu otonom dan harus sesuai dengan karya teologis. Bagi mereka, mempraktikkan aturan dan konsep tata bahasa dari teks Alkitab akan menjadi cara yang tepat untuk memahami iman Kristen. Para tokohnya antara lain Hans W. Frei, George Lindbeck, Stanly Hauerwas, dan David Kelsey. Tipe kedua adalah teologi naratif impure, yang berkiblat ke kota Chicago. Paul Ricouer, David Tracy, Hart, dan Sallie McFague sepakat bahwa narasi adalah genre yang kritis dan terabaikan, di mana kebenaran dan praktik keagamaan penting untuk dibicarakan.

Secara singkat Comstock memilah tiga pokok perbedaan antara teologi naratif pure dan teologi naratif impure, yakni memuat deskripsi, eksplanasi, dan justifikasi. Secara deskriptif, teologi naratif pure tidak memberi ruang untuk tugas apologetis. Sementara itu yang impure tidak setuju dengan ketergantungan yang penuh pada narasi, sebab suatu narasi pasti mengandung klaim historis, psikologis, dan metafisik. ${ }^{39}$ Pada tahap eksplanasi, tipe pure menempatkan doktrin Kristen sebagai regulasi untuk komunitas orang percaya. Sedangkan bagi teolog naratif impure bahasa kekristenan itu diteruskan menjadi bahasa

\footnotetext{
${ }^{38}$ Huyssteen, "Narrative Theology," 769. 698.

${ }^{39}$ Comstock, "Two Types of Narrative Theology," 694-

${ }^{40}$ Ibid., 698-703.

${ }^{41}$ Ibid., 703-709.

${ }^{42}$ Huyssteen, "Narrative Theology," 770.
}

publik, sehingga perlu dikorelasikan secara kritis dengan pandangan filsafat kontemporer, etika, dan ilmu sosial. ${ }^{40}$ Perbedaan ketiga dari kedua tipe itu berkaitan dengan perihal justifikasi narasi Kristen. Bagi teolog naratif pure, pembenaran iman Kristen itu bersifat pragmatis. Sedangkan teolog naratif impure tidak menyetujuinya, sebab kebenaran Kristen menuntut penyelidikan metafisik untuk menentukan apakah kepercayaan Kristen dapat diterima secara rasional. ${ }^{41}$ Sebetulnya, perbedaan dasar keduanya terletak pada dua pokok, yakni problem epistemologis dan hermeneutis. ${ }^{42}$ Teologi naratif pure tampak lebih bersifat eksklusif dalam memanfaatkan disiplin ilmu lain. Sementara itu, teologi naratif impure justru membuka diri (sebagai keharusan) terhadap disiplin ilmu yang lain. Tipe kedua adalah tipe teologi naratif yang kini lebih banyak dipraktikkan, tidak hanya di kalangan Kristen.

\section{Karakteristik Teologi Naratif}

Narasi sebagai realitas kebenaran

Robert Scholes, James Phelan, dan Robert L. Kellogg menyebutkan bahwa sebuah narasi terdiri dari karakteristik utama, kehadiran sebuah cerita dan si pencerita. ${ }^{43}$ Namun pada teologi naratif, si pencerita tidaklah permanen, apalagi hanya berpatokan pada si pencerita pertama. Jika sebuah narasi dianggap sebagai bentuk utama wacana, maka akan berimplikasi pada tindakan menghilangkan perbedaan dan pemisahan antara bahasa dan budaya konvensional. ${ }^{44}$ Implikasi kedua berarti menjelaskan bahwa bentuk narasi tidak bersifat derivatif, melainkan bentuk mandiri. ${ }^{45}$ Implikasi yang terakhir, perlakuan terhadap narasi adalah keniscayaan, bukan

\footnotetext{
${ }^{43}$ Robert Scholes, James Phelan, dan Robert L. Kellogg, The Nature of Narrative (Oxford: Oxford University Press, 2006), 4.

${ }^{44}$ Wesley A. Kort, "Narrative and Theology," Literature and Theology 1, no. 1 (1987): 27, https://doi.org/10.1093/ litthe/1.1.27.

${ }^{45}$ Ibid., 28.
} 
opsional. ${ }^{46}$ Praktik berteologi dalam bentuk kisah individual atau komunal akan lebih mudah dipahami daripada argumen-argumen diskursif. Melalui narasi orang Kristen lebih bisa memahami pentingnya realitas dalam proses pembentukan karakter dan tindakan moral. $^{47}$

Dalam konteks sastra naratif, lebih tepat untuk mengatakan bahwa narasi Alkitab itu history-like, yang berarti bukanlah reportase sejarah, tetapi juga bukan cerita fiksi yang tidak berhubungan dengan sejarah. ${ }^{48}$ Bagi Frei, history-like menjadi fitur penting dari narasi Alkitab yang digunakan dalam pembentukan iman Kristen. ${ }^{49}$ Karena itu, interpretasi adalah masalah menyesuaikan cerita Alkitab ke dunia lain dan cerita lain daripada memasukkan dunia itu ke dalam cerita Alkitab. ${ }^{50}$ Pemahaman ini mengarah pada kemungkinan pengakuan "kebenaran" daripada bertanya apakah itu kisah nyata atau faktual sebagai rekaman dari peristiwa historis, atau bukan. Teologi naratif tidak menuntut sebuah cerita harus bersifat historis, sebab teologi ini tidak memerlukan pengulangan cerita masa lampau.

Ada dua tipe besar naratif, yaitu fiksi (novel dan drama) dan sejarah (diari dan jurnal). Tipe pertama merujuk pada sejarah yang dikarang demi pesan tertentu. Sementara tipe kedua mengarah pada pengertian sejarah yang faktual di masa lampau. Dengan demikian, kalaupun kisah di dalam Alkitab tidak persis sama atau berbeda sama sekali dengan peristiwa historis yang sedang diceritakan, itu semua harus diakui sebagai "kebenaran," sebab kebenaran Alkitab diatur oleh struktur naratifnya. Sejalan dengan pemikiran tersebut, maka seorang teolog naratif harus mengakui otoritas kitab suci yang kanonis, final dan normatif. Dalam penggunaan tipologi, kitab

\footnotetext{
${ }^{46}$ Ibid., 29.

${ }^{47}$ Klaasen, "Practical Theology and Narrative," 461.

${ }^{48}$ Frei, The Eclipse of Biblical Narrative, 10.

${ }^{49}$ Ibid.

${ }^{50}$ Ibid., 131.
}

suci dipahami secara harfiah dan sederhana. Prioritas perhatian berada pada sastra yang sudah ada daripada studi historis Alkitab.

\section{Tradisi sebagai Dasar Berteologi}

Sebagaimana dijelaskan dalam definisi sebelumnya, teologi naratif berupaya memberi makna terhadap teks Alkitab untuk pembaca hari ini (McFague). Pemberian makna itu tidak mungkin lahir sendiri tanpa ada prapendapat sebelumnya. Di dalam praktik berteologi secara naratif, Alkitab tetap menjadi sumber berteologi. Namun, dogma-dogma yang muncul dalam tradisi kekristenan menjadi lensa hermeneutis dalam memaknai teks. Misalnya doktrin Trinitas dijadikan sebagai lensa untuk menafsir keseluruhan teks Alkitab. Penerapan itu, misalnya, bisa terlihat tatkala menafsir kata "Kita" dalam Kejadian 1:26, dimaknai sebagai konsep Trinitas. Tetapi lebih daripada itu, narasi Kristen dan gereja dipakai sebagai pijakan awal untuk merelasikannya dengan kisah di Alkitab, kemudian merefleksikanya dengan narasi kita. Dari sini sebenarnya terlihat ada tiga narasi yang harus direlasikan satu sama lain melalui teologi naratif, yaitu antara tradisi kekristenan, Alkitab, dan orang Kristen (individual dan komunal). Bahkan Soskice dengan tegas berargumen, "all forms of narrative theology grows from Christology." 51

\section{Komunitas sebagai Penafsir dan Sekaligus Pendengar}

Teologi naratif tidak pernah berangkat dari hal-hal yang abstrak, melainkan dari narasi konkret tertentu. Narasi itu harus berakar pada pengalaman khusus komunitas dengan

${ }^{51}$ J.M. Soskice, "Myths, Metaphors and Narrative Theology," dalam Recent Developments in the Philosophy of Language and Their Relevance for the Study of Religious Discourse, Proceedings of the $7^{\text {th }}$ European Conference on Philosophy of Religion (Utrecht University, 1988), 150. 
diri sendiri, dunia, dan Tuhan. ${ }^{52}$ Kata "komunitas" menjadi salah satu kata kunci teologi naratif, sehingga pemaknaan Alkitab untuk kehidupan lebih bersifat komunitarian. Narasi komunal berada lebih tinggi dari narasi individual. Walaupun pada awalnya teologi naratif berupaya mencari relasi di antara semua narasi yang ada, tetapi prosedur berteologi secara naratif dimulai dari tradisi Kristen dan komunitas. Kekristenan adalah entitas komunal yang mempunyai dasar bersama sebagai komunitas. Apa yang diakui bersama, itulah yang menjadi dasar berteologi atau dasar berelasi bersama dengan narasi yang lain.

Secara hermeneutis, sebenarnya kondisi seperti ini menempatkan komunitas Kristen sebagai penfasir teks Alkitab. Mereka menafsir dan memberi makna pada teks seturut apa yang berlaku di komunitasnya dan sesuai dengan tradisi yang dipakai. Dalam hal ini, respons pembaca memang memperoleh porsi besar dalam berteologi, meski tidak bisa sebebas para pembaca modern atau kaum liberal. Jika pembaca modern bisa menjadikan dirinya sendiri sebagai standar dalam menilai, lain halnya dengan teologi naratif yang meletakkan standar penilaian pada apa yang disepakati dalam komunitas. Apa yang dinilai sebagai kebenaran bersama, itulah kebenaran yang bermakna. Si pencerita, si pendengar, dan juga si penafsir memiliki otoritas yang sama dalam pembuatan makna.

\section{Nalar sebagai Alat Interpretasi}

Pada perkembangannya, selain ketiga karakteristik utama di atas, Klaasen menawarkan satu ciri lagi, yaitu "nalar yang terlibat sebagai alat interpretasi" dalam kaitannya dengan pengalaman, dan bukan bersifat teknis atau

\footnotetext{
${ }^{52}$ Alexander Lucie-Smith, Narrative Theology and Moral Theology: The Infinite Horizon (Aldershot: Ashgate, 2007), 1.

${ }^{53}$ Klaasen, "Practical Theology and Narrative," 470.

${ }^{54}$ Ibid., 469-471.
}

abstrak. ${ }^{53}$ Dalam hal ini diperlukan keterlibatan kritis dan dialog dari pengalaman orang-orang percaya dalam berelasi dengan Tuhan. Teologi naratif Klaasen lebih terbuka dengan memberi ruang bagi nalar sebagai keterlibatan kritis dengan komunitas dan sejarah. Karena itu, Klaasen menamakan teologinya sebagai sebagai teologi naratif terbuka (open-ended narrative theology). ${ }^{54}$

\section{Apresiasi terhadap Kontribusi}

Bagi teolog naratif, narasi menjadi unsur signifikan dalam berteologi, dan sangat esensial dalam memahami manusia dan apa yang terjadi pada identitas dalam proses sebagai orang Kristen. ${ }^{55}$ Pada awalnya, mungkin saja teologi naratif bermaksud untuk bisa mengatasiproblem pemaknaan atas teks Alkitab untuk pembaca hari ini (McFague). Ada empat aspek yang menjadi kekuatan teologi naratif, yang bisa dijadikan pertimbangan dalam berteologi: sederhana-praktis, konfesionaldogmatis, relasional, dan induktif.

\section{Sederhana-Praktis}

Dikatakan sederhana atau praktis sebab teologi naratif membuka ruang lebar untuk setiap orang Kristen (termasuk awam) dalam menilai segala sesuatu secara kristianikultural, termasuk dalam berteologi dan menafsir Alkitab. ${ }^{56}$ Tidak ada prosedur kaku dan muskil yang harus dilewati oleh para pembaca. Pengetahuan mengenai disiplin ilmu di sekitar proses penulisan Alkitab pun tidak diperlukan, karena hal itu justru bisa mengganggu pembaca dalam berefleksi. Sama seperti yang Frei pikirkan, bahwa makna teks adalah tepat seperti yang dituliskan. Oleh karena setiap orang mempunyai narasi, tradisi, dan komunitasnya sendiri, maka ia pun bisa berefleksi teologis terhadap Alkitab.

\footnotetext{
${ }^{55}$ George W. Stroup, The Promise of Narrative Theology: Recovering the Gospel in the Church (Atlanta: John Knox, 1981), 8.

${ }^{56}$ Hampton, Narrative Theology as A Hermeneutic Approach, 6.
} 


\section{Konfesional-Dogmatis}

Seperti yang sudah dijelaskan sebelumnya, tradisi merupakan salah satu elemen penting dalam teologi naratif. Teologi ini memberi apresiasi tinggi terhadap tradisi Kristen dan dogma tertentu. ${ }^{57}$ Jika seseorang berasal dari tradisi Protestan, maka teologi naratif akan berfungsi sebagai lensa Kristosentris, trinitarian dan ortodoks dalam memaknai Alkitab. Ini artinya teologi naratif bersifat konfesional, sekaligus dogmatis, sebab antara konfesi dan dogma tidak mungkin terpisahkan. Di sinilah narasi Kristus (misalnya dalam Injil) menjadi model sekaligus direlasikan dengan narasi yang sedang dialami umat atau gereja, baik secara komunal maupun individual.

\section{Relasional}

Menurut Ganzervoort, dimensi sentral pendekatan naratif dalam berteologi adalah mempertimbangkan relasi dengan apa yang sudah diberikan (realitas, fakta-fakta dalam perjalanan hidup seseorang, dan tradisi) dan relasi dengan pribadi-pribadi yang mendengarkan kisah itu (orang yang dianggap penting, dunia yang lebih luas, dan Allah sendiri). ${ }^{58}$ Dalam hal ini, cerita bukan sekedar soal cara penulisan plot atau drama, tetapi merupakan identitas seseorang. Menceritakan narasi seseorang bukan hanya menyampaikan informasi sekuat mungkin, tetapi merupakan cara berada di hadapan orang lain. Bercerita adalah menjalani hidup bersama orang lain. Cerita merupakan bagian integral dari identitas orang tersebut. ${ }^{59}$ Dengan begitu tampak relasi satu dengan yang lain, antara individu, dunia, dan Tuhan.

\section{Induktif}

Kekuatan keempat terletak pada sifatnya yang induktif. Teologi naratif tidak dimulai

\footnotetext{
${ }^{57}$ Klaasen, "Practical Theology and Narrative," 471.

${ }^{58}$ Ganzevoort, "Narrative Approaches," 216.

${ }^{59}$ Klaasen, "Practical Theology and Narrative," 471.

${ }^{60}$ Lucie-Smith, Narrative Theology and Moral Theology, 1.
}

dari prinsip-prinsip abstrak, tetapi dari narasi tertentu yang ada di komunitas. ${ }^{60}$ Ia lebih bersifat induktif daripada deduktif. Komunitas adalah tempat awal dan akhir dalam memaknai teks. Dengan demikian, praktik hermeneutika ini menyebabkan arah pemberian makna teks lebih tepat sasaran, bahkan lebih memuaskan.

Cara berteologi demikian diyakini bisa menjawab problem-problem ekumenis yang muncul di era pascamodern, di mana teologi liberal tidak mampu menyediakan solusi yang memuaskan. Ternyata ketiadaan kriteria doktrin tunggal dari teologi liberal telah membuat kekristenan (khususnya di Amerika Utara, karena ini merupakan konteks awal teologi naratif muncul) tidak siap dalam menyikapi perubahan tren ekumenis dan agama saat itu. ${ }^{61}$ Di sinilah peran teologi naratif begitu diharapkan, yakni mampu menjelaskan klaim kekristenan bahwa Alkitab ada untuk semua kalangan.

\section{Evaluasi terhadap Reduksi}

Di satu sisi, teologi naratif dinilai dapat berkontribusi bagi teologi Kristen, namun di lain sisi, justru bisa mereduksi kebenaran teologi Kristen. Tentang hal itu, dijabarkan pada bagian evaluasi berikut ini.

\section{Hermeneutika Pascamodern}

Hakikat teologi naratif jelas tidak sama dengan hermeneutika, meskipun telah dipraktikkan sebagai lensa dalam membaca teks Alkitab. Kalaupun ingin demikian maka terdapat sejumlah kejanggalan yang harus dikritisi. Pertama, teologi naratif lahir di era pascamodern, yang tampil sebagai respons terhadap teologi modern. Berkenaan dengan hal itu, maka paradigma tafsir yang digunakan adalah membaca atau menafsir teks dengan orientasi

\footnotetext{
${ }^{61}$ Kartika Diredja, “Teologi Postliberal,” dalam Teologiteologi Kontemporer, diedit oleh Jan S. Aritonang (Jakarta: BPK Gunung Mulia, 2018), 67.
} 
pembaca dan dunianya atau respons pembaca. ${ }^{62}$ Dalam perspektif injili, seperti yang disampaikan Alister McGrath, pascaliberalisme telah mereduksi konsep kebenaran menjadi "konsistensi internal." ${ }^{63}$ Menurutnya, kekristenan tidak hanya tentang menafsir identitas Yesus atau menjelaskan tata bahasa iman yang koheren, namun tentang mengakui kebenaran Yesus Kristus sebagai Juruselamat dan Tuhan. ${ }^{64}$ Ciri khas pascamodernisme adalah skeptisismenya tentang peran sentral yang diberikan pada akar dan pemikiran rasional. Ditambah lagi, cara penalaran metafisika, perspektif kebenaran relasional, pluralisme etis, dan relativisme budaya ${ }^{65} \mathrm{Ke}-$ dua, karena bertentangan dengan studi modern, maka teologi ini (khususnya tipe teologi naratif pure) menolak objektivitas yang dihasilkan melalui pemanfaatan disiplin ilmu lain. Sebagaimana yang Frei tandaskan bahwa arti teks tepat seperti yang dituliskan, maka teks Alkitab bersifat otonom. Sangat tertutup dan formalistik. ${ }^{66}$ Posisi ini mengindikasikan bahwa historisitas di sekitar penulisan teks tidaklah penting. Fokus penafsiran bukanlah apa yang dimaksudkan oleh penulis.

\section{Pengabaian Historisitas dan Keragaman Genre Alkitab}

Di dalam Alkitab genre sastra yang dipakai tidak hanya naratif tetapi juga puisi, nubuat, hukum, dan peribahasa. Teolog naratif akan mengalami kesulitan saat menafsir teks-teks yang bergenre selain narasi, sebab bagi mereka semua, narasi telah mengendalikan, arogan dan menindas orang-orang yang tidak setuju dengannya. ${ }^{67}$ Makna naratif kisah Alkitab tentu berbeda dengan kisah kesusastraan

\footnotetext{
${ }^{62}$ Tentang paradigma tafsir dapat membaca John $\mathrm{H}$. Hayes, ed., Methods of Biblical Interpretation: Excerpted from the Dictionary of Biblical Interpretation (Nashville: Abingdon, 2004), 169.

${ }^{63} \mathrm{McGrath}, A$ Passion for Truth, 153.

${ }^{64}$ Ibid., 154.

${ }^{65}$ Huyssteen, "Narrative Theology," 772-774.

${ }^{66}$ Himawan, "Tekstualitas dan Intratekstualitas dalam Hermeneutika Pascaliberalisme," 153-156.
}

lainnya. Setidaknya Paul Ricoeur mengingatkan hal itu dalam tiga argumentasi. Pertama, kisah Alkitab bersifat "sakral," tidak sama dengan sastra biasa lain. Dikatakan sakral karena cerita-cerita di dalam Alkitab adalah kisah lampau yang diceritakan ulang dengan alasan tertentu. Seluruh kisah dalam Alkitab merupakan kisah selektif yang bersifat liturgis karena akan bermakna saat diperagakan kembali dalam kultus. ${ }^{68}$ Kedua, kisah Alkitab berkaitan dengan relasi antara cerita dan sejarah, dan hal ini diabaikan oleh teologi naratif. Ketiga, makna teologis dan religius cerita diperoleh dari komposisinya dengan model wacana lain. ${ }^{69}$

\section{Fideisme Tradisional-Dogmatis}

Istilah "tradisional" di sini, bukan terminologi budaya, melainkan berhubungan dengan tradisi kekristenan, misalnya tradisi Protestan, tradisi Katolik, tradisi ortodoks, tradisi Pentakostal, dan sebagainya. Karena itu dilekatkanlah istilah "dogmatis" untuk memperjelas apa yang penulis maksudkan. Jika tradisi dijadikan sumber utama berteologi, maka ada kemungkinan orang Kristen dapat menutup diri terhadap kritik dan saran dari pihak luar. Secara epistemik, teologi naratif sama dengan "fideisme" gerejawi, yang gagal mencari pembenaran rasional yang memadai, dan bahkan mungkin memusuhi kebaikan nalar. ${ }^{70}$ Praktik berteologi seperti ini mengingatkan kita pada kehidupan gereja di abad Pertengahan. Di masa itu tidak banyak penafsiran Alkitab baru yang muncul, sehingga mengandalkan hasil tafsiran bapa-bapa gereja mula-mula. Tradisi bapa-bapa gereja dijadikan sebagai sumber berteologi, bahkan dalam memahami dan memaknai Alkitab. Di masa itu pula, Alkitab

\footnotetext{
${ }^{67}$ McGrath, A Passion for Truth, 190.

${ }^{68}$ Paul Ricoeur, Figuring the Sacred: Religion, Narrative, and Imagination, terj. David Pellauer, ed. Mark I. Wallace (Minneapolis: Fortress, 1995), 243.

${ }^{69}$ Ibid., 244.

${ }^{70}$ Marshall, "Introduction," dalam The Nature of Doctrine, xii.
} 
hanya boleh dimiliki oleh pejabat gereja, sedangkan orang awam tinggal menerima saja makna teks dari gereja.

\section{Sektarian}

Alih-alih menentang paradigma tafsir modern yang terlalu subjektif karena terlalu individualistis, teologi naratif justru melahirkan subjektivitas bentuk baru, yaitu "komunitarian." Jadi sebenarnya standar berteologi tidak berubah secara esensial, hanya wujud si penafsir yang bergeser dari individu ke komunitas. Perihal komunitarian memang menjadi ciri khas teologi pascaliberal atau pascamodern. Tetapi dalam hal ini, rasanya lebih tepat menyebut sifat teologi naratif adalah "sektarian" (karena membahas kekristenan), daripada komunitarian. ${ }^{71}$ Bisa saja ini adalah lanjutan dari evaluasi kedua, yaitu tradisionaldogmatis, sebab antara tradisi dan komunitas tidak terpisahkan. Dalam berteologi secara praktis, celah inilah yang coba diatasi oleh Klaasen dengan mengonstruksi teologi naratif menjadi lebih terbuka.

Sifat induktif teologi naratif berangkat dari komunitas dan berakhir di komunitas, tempat seseorang berada dan tinggal. Di sini akan timbul masalah besar dan rumit, sebab implikasi evaluasi ini tidak akan bisa menyelesaikan perbedaan standar kebenaran dari seluruh komunitas. Di dunia ini kekristenan terdiri dari sejumlah varian komunitas dan tradisi. Apakah mungkin standar yang berlaku pada suatu komunitas tertentu bisa berlaku dan diterima juga oleh komunitas lainnya? Dalam praktiknya pun teologi naratif akan mengalami kesulitan saat mendialogkan narasi teks antarkomunitas. Relativisme pascamodern dan skeptisisme ini akan gagal menjelaskan universalitas dan objektivitas kebenaran, khususnya kebenaran doktrin Kristen. Jika ada istilah interfaith, interkultural, dan interreligius, apakah mungkin akan muncul inter- dogmatis? Kekhawatiran lainnya adalah kondisi seperti ini akan menonjolkan identitas masing-masing komunitas dan tradisi, yang berakibat pada perilaku mempertajam perbedaan.

\section{Pragmatisme}

Mengulangi sekali lagi apa yang dikatakan McFague bahwa program berteologi supaya Injil bisa didengar orang Kristen masa kini, maka orientasi teologi naratif sudah sangat jelas. Ditambah lagi dengan konstelasi istilah "respons pembaca," "tradisi," "dogma," "komunitas," "bahasa," dan "budaya" yang menunjukkan dimensi pragmatisme dalam teologi naratif. Hasil berteologi dan menafsir dikatakan memuaskan jika sesuai dengan kebutuhan komunitas bersama. Sebenarnya manfaat teologi ini menjadi lebih bersifat personal ketimbang komunal. Komunitas hanya dijadikan instrumen untuk mengajak seseorang bisa memaknai dirinya sendiri, untuk menjaga identitas tetap bertahan dalam komunitasnya. Pragmatisme yang disuguhkan adalah keberterimaan akan makna teks bagi setiap orang dalam sebuah komunitas. Narasi seseorang adalah kualitas pengalamannya sendiri, yang bisa direlasikan dan didialogkan, terutama dimulai dari narasi Alkitab, narasi Kristus dan narasi komunitas.

\section{KESIMPULAN}

Paradigma tafsir teologi naratif adalah mencari makna di "depan teks." Teks Alkitab dilihat seperti apa yang sudah tertulis, lalu merelasikannya dengan narasi diri, tradisi dan komunitas di mana orang Kristen berefleksi secara teologis.

Ada empat aspek yang menjadi kontribusi teologi naratif, yaitu: sederhana-praktis, konfesional-dogmatis, relasional, dan induktif. Sebagai lensa hermeneutis, teologi naratif diakui banyak menolong orang Kristen untuk

${ }^{71}$ Ibid., xiii. 
berdialog dengan teks Alkitab dan komunitasnya. Apalagi tradisi dan dogma kekristenan diakomodasi di dalamnya. Karena sifat ortodoks ajaran gereja begitu penting dalam teologi naratif, maka teologi ini tampaknya lebih mudah diterima dan dipraktikkan oleh orang Kristen, khususnya jemaat awam.

Namun kemungkinan kebenaran tereduksi pun patut menjadi pertimbangan dalam memakai teologi ini. Pengabaiannya terhadap historisitas Alkitab, keragaman genre Alkitab selain narasi, serta disiplin ilmu lainnya adalah masalah krusial yang tidak bisa ditoleransi, sebab tindakan itu telah menutup objektivitas kebenaran teks Alkitab. Kebenaran hanya bersifat relatif dan sektarian. Di sisi lain, sepertinya manfaat teologi ini lebih bersifat personal ketimbang komunal. Komunitas hanya dijadikan instrumen untuk mengajak seseorang bisa memaknai dirinya sendiri, untuk mempertahankan identitasnya di tengah komunitas.

Adanya sifat kontributif dan reduktif dari teologi naratif akan memengaruhi praktik tafsir orang Kristen terhadap Alkitab. Meski demikian, teologi naratif harus dibedakan dengan heremeneutika. Ia merupakan salah satu lema dalam teologi Kristen, sekaligus lensa teoritis untuk menerapkan hasil interpretasi teks sebagai pengajaran teologis, dalam berteologi secara praktis.

\section{PERNYATAAN PENULIS}

\section{Kontribusi dan Tanggung Jawab Penulis}

Penulis bertanggung jawab atas analisis, interpretasi dan diskusi hasil penelitian. Penulis telah membaca dan menyetujui naskah akhir.

\section{Konflik Kepentingan}

Penulis menyatakan tidak memiliki konflik kepentingan apa pun yang dapat memengaruhinya dalam penulisan artikel ini.

\section{REFERENSI}

Comstock, Gary L. "Two Types of Narrative Theology." Journal of the American Academy of Religion LV, no. 4 (1987): 687-717. https://doi.org/10.1093/jaarel/ LV.4.687.

Diredja, Kartika. "Teologi Postliberal." Dalam Teologi-teologi Kontemporer, diedit oleh Jan S. Aritonang. Jakarta: BPK Gunung Mulia, 2018.

Eskola, Timo. A Narrative Theology of the New Testament: Exploring the Metanarrative of Exile and Restoration. Tübingen: Mohr Siebeck, 2015.

Fackre, Gabriel. "Narrative Theology: An Overview." Interpretation: A Journal of Bible and Theology 37, no. 4 (Oktober 1983): 340-352. https://doi.org/10.1177/ 002096438303700402.

Ford, David F. "Narrative Theology.” Dalam The SCM Dictionary of Biblical Interpretation, diedit oleh R.J. Coggins dan J.L. Houlden, 489-491. London: SCM, 2003.

Frei, Hans W. The Eclipse of Biblical Narrative: A Study in Eighteenth and Nineteenth Century Hermeneutics. New Haven: Yale University Press, 1974.

Ganzevoort, R. Ruard. "Narrative Approaches." Dalam The Wiley-Blackwell Companion to Practical Theology, diedit oleh Bonnie J. Miller-McLemore, 214-223. Chichester: Wiley-Blackwell, 2012.

Goodson, Jacob L. Narrative Theology and the Hermeneutical Virtues: Humility, Patience, Prudence. Lanham: Lexington, 2015.

Hampton, David. Narrative Theology as $A$ Hermeneutic Approach. Morrisville: Lulu, 2009.

Harvey, T. "Narrative Theology." Dalam Global Dictionary of Theology: A Resource for the Worldwide Church, Diedit oleh William A. Dyrness dan Veli-Matti Kärkkäinen, 598-602. Downers Grove: InterVarsity, 2009.

Hauerwas, Stanley. The Hauerwas Reader. Diedit oleh John Berkman dan Michael 
G. Cartwright. Durham: Duke University Press, 2001.

- Why Narrative? Readings in Narrative Theology. Eugene: Wipf \& Stock, 1997.

Hayes, John H., ed. Methods of Biblical Interpretation: Excerpted from the Dictionary of Biblical Interpretation. Nashville: Abingdon, 2004.

Himawan, Andreas. "Tekstualitas dan Intratekstualitas dalam Hermeneutika Pascaliberalisme." Veritas : Jurnal Teologi dan Pelayanan 1, no. 2 (March 2, 2000): 149-157. https://doi.org/10.36421/veritas.v1i2.43.

Huyssteen, Wentzel van. "Narrative Theology: An Adequate Paradigm for Theological Reflection?" HTS Teologiese Studies / Theological Studies 45, no. 4 (Januari 1989): 767-777. https://doi.org/10.4102/ hts.v45i4.2327.

Jones, L. Gregory. "Narrative Theology." Dalam The Blackwell Encyclopedia of Modern Christian Thought, diedit oleh Alister E. McGrath, 395-397. Oxford: Blackwell, 1993.

Klaasen, John. "Practical Theology and Narrative: Contours and Markers." Stellenbosch Theological Journal 3, no. 2 (Desember 2017): 457-475. https://doi.org/10.17570/ stj.2017.v3n2.a21.

Knight, John Allan. Liberalism versus Postliberalism: The Great Divide in TwentiethCentury Theology. Oxford: Oxford University Press, 2013.

Kort, Wesley A. "Narrative and Theology." Literature and Theology 1, no. 1 (1987): 2738. https://doi.org/10.1093/litthe/1.1.27.

Lindbeck, George A. The Nature of Doctrine: Religion and Theology in A Postliberal Age. $25^{\text {th }}$ Anniversary Edition. Louisville: Westminster John Knox, 2009.

Lucie-Smith, Alexander. Narrative Theology and Moral Theology: The Infinite Horizon. Aldershot: Ashgate, 2007.

McFague, Sallie. Metaphorical Theology: Models of God in Religious Language. Philadelphia: Fortress, 1982.
- Speaking in Parables: A Study in Metaphor and Theology. Philadelphia: Fortress, 1975.

McGrath, Alister E. A Passion for Truth: The Intellectual Coherence of Evangelicalism. Downers Grove: InterVarsity, 1996.

Navone, John. "Narrative Theology and Its Uses: A Survey." Irish Theological Quarterly 52, no. 3 (September 1986): 212-230. https://doi.org/10.1177/002114008605200 304.

Pambudi, Himawan T. "Narasi Bima Bertemu Dewaruci: Metode Teologi Injili di Indonesia dalam Era Pascamodern." Jurnal Amanat Agung 7, no. 2 (2011): 289-311.

Ricoeur, Paul. Figuring the Sacred: Religion, Narrative, and Imagination. Diterjemahkan oleh David Pellauer. Diedit oleh Mark I. Wallace. Minneapolis: Fortress, 1995.

Scholes, Robert, James Phelan, dan Robert L. Kellogg. The Nature of Narrative. Oxford: Oxford University Press, 2006.

Soskice, J.M. "Myths, Metaphors and Narrative Theology." Dalam Recent Developments in the Philosophy of Language and Their Relevance for the Study of Religious Discourse, Proceedings of the $7^{\text {th }}$ European Conference on Philosophy of Religion, 130-150. Utrecht University, 1988.

Stroup, George W. "Narrative Theology." Dalam The Cambridge Dictionary of Christian Theology, diedit oleh Ian A. McFarland, David A.S. Fergusson, Karen Kilby, dan Iain R. Torrance, 331332. Cambridge: Cambridge University Press, 2011.

- The Promise of Narrative Theology: Recovering the Gospel in the Church. Atlanta: John Knox, 1981.

Vanhoozer, Kevin J. The Drama of Doctrine: $A$ Canonical-Linguistic Approach to Christian Theology. Louisville: Westminster John Knox, 2005. 